\title{
PEMBUATAN BAHAN PELUNAK ALAMI UNTUK KOMPON KARET MELALUI REAKSI HIDROGENASI MINYAK JARAK CASTOR
}

\author{
Preparation of Natural Plasticizer for Rubber Compound \\ by Castor Oil Hydrogenation
}

\author{
Santi PUSPITASARI dan Adi CIFRIADI
}

Pusat Penelitian Karet

Jalan Salak Nomor 1 Bogor 16151

Email : shanty_bptkbgr@yahoo.co.id, cifriadi9748@gmail.com

Diterima : 3 Juni 2013 / Direvisi : 1 Agustus 2013 / Disetujui : 18 Oktober 2013

\begin{abstract}
Plasticizer is a chemical substance added to rubber compounding to soften rubber in order to ease the mixing and shorten the compounding time. Modified castor oil has a chance to be developed as natural plasticizer to substitute petroleum-based plasticizer. This research studied the synthesis of natural plasticizer by hydrogenation of castor oil. The research was began with addition of various concentration of $\mathrm{N}_{2} \mathrm{H}_{4} 55 \%$ and $\mathrm{H}_{2} \mathrm{O}_{2} 42 \%$ to $300 \mathrm{ml}$ castor oil at 25 and $40^{\circ} \mathrm{C}$ for 7 hours. At the end of the reaction, water was separated. Pure hydrogenated castor oil (HCO) was characterized. The best specification of HCO was then synthesize at higher capacity. The result showed that during the hydrogenation there were changes in temperature, color, fase, foam and gas. Charcterization of $\mathrm{HCO}$ indicated that optimum condition reached at concentration of $\mathrm{N}_{2} \mathrm{H}_{4} 55 \%$ as 2 $\mathrm{M}, \mathrm{H}_{2} \mathrm{O}_{2} 42 \%$ as $0.6 \mathrm{M}$, and $40^{\circ} \mathrm{C}$. Based on its iod number, the $\mathrm{HCO}$ belonged in the group of hydrogenated vegetable oil as plasticizer Type II.
\end{abstract}

Keywords : Rubber, plasticizer, castor oil, hydrogenation

\section{Abstrak}

Bahan pelunak karet merupakan salah satu bahan kimia yang ditambahkan saat pembuatan kompon untuk melunakan karet sehingga memudahkan pencampuran dan mempersingkat waktu pengkomponan. Minyak jarak castor termodifikasi berpeluang dikembangkan sebagai bahan pelunak karet alami yang dapat mensubstitusi bahan pelunak berbasis minyak bumi. Pada penelitian ini dipelajari pembuatan bahan pelunak karet alami dari minyak jarak castor melalui reaksi hidrogenasi. Tahapan dalam penelitian mengikuti alur berikut : $300 \mathrm{ml}$ minyak jarak castor ditambah dengan $\mathrm{N}_{2} \mathrm{H}_{4} 55 \%$ dan $\mathrm{H}_{2} \mathrm{O}_{2} 42 \%$ pada berbagai konsentrasi setelah tercapai suhu reaksi $\left(25^{\circ} \mathrm{C}\right.$ dan $\left.40^{\circ} \mathrm{C}\right)$ selama 7 jam. Pada akhir reaksi, air yang terbentuk dipisahkan dari minyak jarak castor terhidrogenasi. Minyak jarak castor terhidrogenasi bebas air kemudian dikarakterisasi. Minyak jarak castor terhidrogenasi dengan spesifikasi terbaik selanjutnya disintesis pada skala yang lebih besar. Hasil percobaan menunjukkan bahwa selama reaksi terjadi perubahan suhu warna dan fasa, serta timbul buih dan gas. Karakterisasi minyak jarak castor terhidrogenasi mengindikasikan bahwa kondisi optimal reaksi hidrogenasi diperoleh pada konsentrasi $\mathrm{N}_{2} \mathrm{H}_{4} 55 \%$ sebesar $2 \mathrm{M}, \mathrm{H}_{2} \mathrm{O}_{2} 42 \%$ sebesar $0,6 \mathrm{M}$, dan suhu reaksi $40^{\circ} \mathrm{C}$. Berdasarkan nilai bilangan iod, minyak jarak castor terhidrogenasi tersebut termasuk dalam bahan pelunak dari golongan minyak nabati terhidrogenasi Tipe II.

Kata kunci : Karet, bahan pelunak, minyak jarak castor, hidrogenasi

\section{PENDAHULUAN}

Bahan pelunak karet (rubber plasticizer) merupakan salah satu bahan kimia utama yang ditambahkan saat pembuatan kompon karet. Bahan pelunak karet berfungsi untuk melunakkan karet, memudahkan pencampuran bahan kimia terutama bahan pengisi ke dalam kompon karet, mempersingkat waktu, menurunkan suhu pengkomponan, menghambat terjadinya waktu pra vulkanisasi, serta dapat memudahkan pembentukan barang jadi karet (Suseno, 1990). Mengingat fungsi bahan pelunak yang cukup penting maka kebutuhan bahan pelunak dalam industri manufaktur barang jadi karet relatif tinggi. Sebagai contoh, dalam produksi ban kendaraan diperlukan dosis bahan pelunak sebanyak 8-20\%. Berdasarkan data BPS (2010), total ekspor Indonesia untuk semua jenis ban kendaraan mencapai 4,2 juta ton 
atau 50 juta unit. Apabila dalam pembuatan ban digunakan sebanyak $15 \%$ bahan pelunak maka kebutuhan bahan pelunak untuk industri ban kendaraan sekitar 630.000 ton. Bahan pelunak tersebut seluruhnya berasal dari bahan pelunak sintetis yang diperoleh dari hasil pengolahan minyak bumi. Bahan pelunak karet berbasis minyak bumi berdasarkan struktur molekulnya dibedakan menjadi bahan pelunak golongan parafinik, aromatik, dan naftanik (Arizal, 1990). Bahan pelunak golongan parafinik memiliki struktur kimia rantai lurus, aromatik memiliki struktur kimia dalam bentuk cincin benzena, dan naftanik memiliki struktur kimia dalam bentuk cincin.

Deposit minyak bumi yang semakin menipis dan fungsi utamanya sebagai bahan baku bahan bakar minyak menuntut dilakukannya penelitian tentang pembuatan bahan pelunak karet bersumber dari bahan alami untuk menggantikan bahan pelunak karet yang berbasis minyak bumi. Bahan pelunak alami (natural plasticizer) berpeluang dikembangkan dari minyak nabati seperti minyak jarak castor. Minyak jarak castor yang termasuk minyak nabati pada dasarnya bersifat sebagai physical softener yaitu bahan yang dapat meningkatkan plastisitas kompon sehingga memudahkan proses pencampuran (McMillan, 1959). Untuk mendapatkan kinerja minyak jarak castor sebagai bahan pelunak karet alami yang optimal, maka minyak jarak castor perlu dimodifikasi secara kimiawi misal melalui reaksi epoksidasi atau hidrogenasi. Dengan modifikasi kimiawi akan mengubah struktur molekul trigliserida dalam minyak jarak castor. Pada reaksi hidrogenasi, senyawa hidrogen akan mengadisi ikatan rangkap $\mathrm{C}=\mathrm{C}$ dalam trigliserida menjadi ikatan jenuh $\mathrm{C}-\mathrm{C}$.

Reaksi hidrogenasi dapat berlangsung tanpa menggunakan gas hidrogen melainkan dengan senyawa pengganti hidrogen (senyawa donor hidrogen). Reaksi hidrogenasi ini dikenal dengan reaksi transfer hidrogenasi (Naglic et al., 1998). Senyawa yang banyak digunakan pada reaksi transfer hidrogenasi adalah senyawa diimide. Menurut Smit et al (2008), senyawa diimide bersifat sangat reaktif sehingga hanya dapat digunakan secara insitu dalam suatu reaksi hidrogenasi. Salah satu metode dalam pembangkitan senyawa diimide diungkapkan oleh Kraft et al (2011) yang menyatakan bahwa senyawa diimide dapat disintesis melalui reaksi oksidasi hidrasin hidrat $\left(\mathrm{N}_{2} \mathrm{H}_{4}\right)$ oleh hidrogen peroksida $\left(\mathrm{H}_{2} \mathrm{O}_{2}\right)$ atau oksigen $\left(\mathrm{O}_{2}\right)$ dengan penambahan katalis $\mathrm{Cu}$.

Laju reaksi transfer hidrogenasi ditentukan oleh suhu reaksi, katalis, dan $\mathrm{pH}$. Katalis yang berasal dari ion tembaga seperti Cu (II) asetat, $\mathrm{Cu}$ (II) sulfat, dan Cu (II) perklorat dianggap sebagai katalis yang paling sesuai untuk reaksi hidrogenasi dengan senyawa diimide (Parker dan Ruthenburg, 1995 dalam Lin et al., 2003). Lin et al (2003) menginformasikan bahwa saat $\mathrm{pH}>8$ laju reaksi naik dengan cepat, dan pada $\mathrm{pH}=10$, laju reaksi mencapai maksimum. Pada suhu $25^{\circ} \mathrm{C}$ reaksi berjalan sangat lambat, dan seiring kenaikan suhu maka akan terjadi kenaikan laju reaksi.

Lin et al (2003) telah melakukan penelitian tentang reaksi pembentukan senyawa diimide menggunakan hidrasin hidrat dan hidrogen peroksida berkatalis ion tembaga. Hasil penelitian tersebut mengungkapkan bahwa reaksi redoks antara hidrasin hidrat dan hidrogen peroksida merupakan reaksi orde satu pada konsentrasi hidrasin hidrat sebesar 0,04-2M dan hidrogen peroksida sebesar 0,027-0,6M serta suhu reaksi $25-75^{\circ} \mathrm{C}$. Mengacu pada hasil penelitian Lin et al. (2003), tersebut maka pada penelitian ini akan dipelajari pembuatan bahan pelunak karet alami dari minyak jarak castor melalui reaksi hidrogenasi.

\section{BAHAN DAN METODE}

Penelitian tentang pembuatan bahan peluak karet alami melalui reaksi hidrogenasi minyak jarak castor telah dilakukan di Pusat Penelitian Karet pada bulan Juli hingga November 2012. Bahan utama berupa minyak jarak castor diperoleh dari PT. Kimia Farma Semarang, hidrasin hidrat (teknis) dari Arch Chemical Singapura, dan hidrogen peroksida (teknis) dari Setia Guna Bogor. Metode reaksi hidrogenasi minyak jarak castor menerapkan kondisi operasi pada berbagai konsentrasi pereaksi dan suhu reaksi. Waktu reaksi ditetapkan selama 7 jam dan suhu reaksi pada suhu ruang $\left( \pm 25^{\circ} \mathrm{C}\right)$ dan 
$40^{\circ} \mathrm{C}$. Konsentrasi hidrasin hidrat $55 \%$ divariasikan sebesar $2 \mathrm{M}$, 3M, dan $4 \mathrm{M}$ sedangkan hidrogen peroksida sebesar $0 \mathrm{M}$; $0,6 \mathrm{M}$; dan 1,2M. Pada konsentrasi hidrogen peroksida sebesar OM dianggap bahwa reduksi hidrasin hidrat menggunakan oksigen yang diambil dari udara.

Tahapan dalam percobaan sebagai berikut : $300 \mathrm{ml}$ minyak jarak castor dituangkan ke dalam gelas piala. Minyak jarak castor dalam gelas piala ditambah dengan hidrasin hidrat apabila sudah tercapai suhu yang dikehendaki. Hidrogen peroksida ditambahkan ke dalam campuran minyak jarak castor dan hidrasin hidrat pada kecepatan tetesan $2 \mathrm{ml}$ /menit. Selama reaksi diamati perubahan yang terjadi meliputi perubahan warna, fasa, dan suhu. Pada akhir reaksi, minyak jarak castor terhidrogenasi dituangkan dalam corong pemisah agar terpisah dari air. Air merupakan hasil samping reaksi hidrogenasi. Pemisahan air yang masih terdispersi dalam minyak jarak castor terhidrogenasi dilanjutkan menggunakan bahan penyerap air yaitu $\mathrm{Na}_{2} \mathrm{SO}_{4}$ sebanyak $5 \%(\mathrm{~b} / \mathrm{v})$. Campuran didiamkan selama \pm 20 jam. Tahap selanjutnya, $\mathrm{Na}_{2} \mathrm{SO}_{4}$ disaring agar terpisah dari minyak jarak castor terhidrogenasi.

Minyak jarak castor bebas air kemudian dikarakterisasi sifat kimianya meliputi uji bilangan iod, uji bilangan asam, uji berat jenis, uji kekentalan (viskositas Brookfield), dan FTIR. Minyak jarak castor terhidrogenasi dengan spesifikasi terbaik selanjutnya disintesis pada skala yang lebih besar (500 $\mathrm{ml}$ minyak jarak castor/batch). Minyak jarak castor terhidrogenasi skala besar yang telah diperoleh kemudian diuji sifat fisik dan kimia mengacu pada pengujian bahan pelunak karet secara umum. Parameter pengujian meliputi kekentalan, flash point, pour point, keasaman, kadar abu, warna, dan visualisasi.

\section{HASIL DAN PEMBAHASAN}

Perubahan yang mengindikasikan terjadinya reaksi hidrogenasi minyak jarak castor oleh senyawa diimide terangkum dalam Gambar 1 dan Tabel 1 .

Kondisi operasi reaksi hidrogenasi minyak jarak castor terutama konsentrasi pereaksi dan suhu reaksi berpengaruh terhadap jalannya reaksi. Pada awal reaksi antar pereaksi tidak saling bercampur, namun seiring berjalannya pengadukan menyebabkan molekul hidrasin hidrat dan hidrogen peroksida mulai bercampur dengan minyak jarak castor dan warna campuran berubah dari kuning jernih menjadi putih keruh atau kuning keruh. Warna putih keruh terjadi pada reaksi hidrogenasi tanpa penambahan hidrogen peroksida. Jumlah buih yang timbul pada reaksi hidrogenasi minyak jarak castor berbanding lurus dengan peningkatan konsentrasi hidrogen peroksida. Kuantitas buih dapat mencapai 50-100\% dari volume awal.

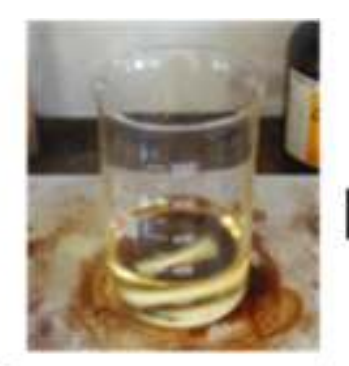

Pencampuran awal Initial mixing
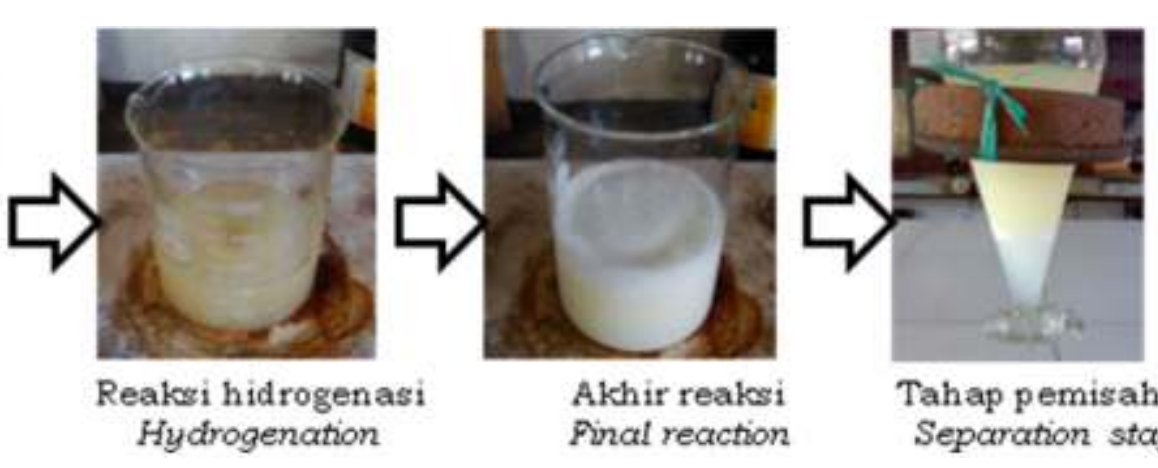

Tahap pemisahan Separation stage

Gambar 1. Perubahan selama reaksi hidrogenasi

Figure 1. Changes during castor oil hydrogenation 
Tabel 1. Kondisi reaksi hidrogenasi minyak jarak castor Table 1. Hydrogenation of castor oil condition

\begin{tabular}{|c|c|c|c|c|}
\hline \multicolumn{2}{|c|}{$\begin{array}{l}\text { Konsentrasi } \\
\text { Concentration } \\
\text { (M) }\end{array}$} & \multirow{2}{*}{$\begin{array}{c}\text { Suhu eksotermis tertinggi } \\
\text { Highest exothermic } \\
\text { temperature } \\
\left({ }^{\circ} \mathrm{C}\right)\end{array}$} & \multirow[t]{2}{*}{$\begin{array}{l}\text { Buih dan gas } \\
\text { Foam and gas }\end{array}$} & \multirow[t]{2}{*}{$\begin{array}{c}\text { Warna } \\
\text { Color }\end{array}$} \\
\hline $\mathrm{N}_{2} \mathrm{H}_{4} \cdot \mathrm{H}_{2} \mathrm{O}$ & $\mathrm{H}_{2} \mathrm{O}_{2}$ & & & \\
\hline \multicolumn{5}{|c|}{ Suhu reaksi $=25^{\circ} \mathrm{C}$} \\
\hline & 0 & 30 & Tidak ada & Putih keruh \\
\hline \multirow[t]{3}{*}{2} & 0,6 & 32 & Banyak & Kuning keruh \\
\hline & 1,2 & 38 & Banyak & Putih keruh \\
\hline & 0 & 29 & Tidak ada & Putih keruh \\
\hline \multirow[t]{3}{*}{3} & 0,6 & 38 & Banyak & Kuning keruh \\
\hline & 1,2 & 41 & Banyak & Kuning keruh \\
\hline & 0 & 31 & Tidak ada & Putih Keruh \\
\hline \multirow[t]{4}{*}{4} & 0,6 & 38 & Banyak & Kuning keruh \\
\hline & 1,2 & 55 & Banyak & Kuning keruh \\
\hline & & Suhu reaksi $=40$ & & \\
\hline & 0 & 53 & Sedikit & Putih keruh \\
\hline \multirow[t]{3}{*}{2} & 0,6 & 42 & Banyak & Kuning keruh \\
\hline & 1,2 & 72 & Banyak & Kuning keruh \\
\hline & 0 & 51 & Tidak ada & Putih keruh \\
\hline \multirow[t]{3}{*}{3} & 0,6 & 74 & Banyak & Kuning keruh \\
\hline & 1,2 & 86 & Banyak & Kuning keruh \\
\hline & 0 & 54 & Sedikit & Putih keruh \\
\hline \multirow[t]{2}{*}{4} & 0,6 & 58 & Banyak & Kuning keruh \\
\hline & 1,2 & 55 & Banyak & Kuning keruh \\
\hline
\end{tabular}

Indikasi penting lain dalam reaksi hidrogenasi minyak jarak castor ditunjukkan oleh terjadinya peningkatan suhu reaksi. Peningkatan suhu tertinggi dicapai pada reaksi hidrogenasi minyak jarak castor dengan penambahan hidrasin hidrat $55 \%$ sebesar $3 \mathrm{M}$ dan hidrogen peroksida sebesar $1,2 \mathrm{M}$ pada suhu reaksi sebesar $40^{\circ} \mathrm{C}$ yang mencapai $86^{\circ} \mathrm{C}$. Pada konsentrasi hidrasin hidrat yang sama, peningkatan konsentrasi hidrogen peroksida dapat meningkatkan suhu eksotermis. Hal ini berarti bahwa hidrogen peroksida bersifat sebagai oksidator yang lebih kuat daripada oksigen pada reaksi hidrogenasi. Suhu eksotermis tertinggi terjadi cepat sekitar menit ke-13 sampai 15 . Setelah melewati suhu eksotermis tertinggi, suhu kembali turun secara bertahap. Perubahan suhu selama reaksi ditunjukkan pada Gambar 2 dan 3. Perubahan suhu pada kondisi awal sebesar $40^{\circ} \mathrm{C}$ berlangsung tidak teratur disebabkan karena pengendalian suhu dilakukan manual. 


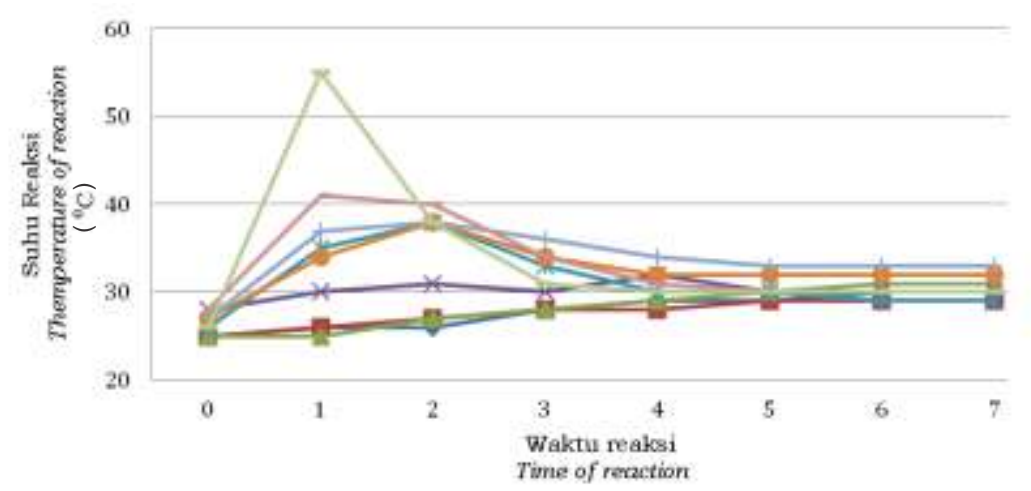

Gambar 2. Perubahan suhu reaksi pada kondisi awal $25^{\circ} \mathrm{C}$

Figure 2. Temperature of reaction changes at initial temperature of $25^{\circ} \mathrm{C}$

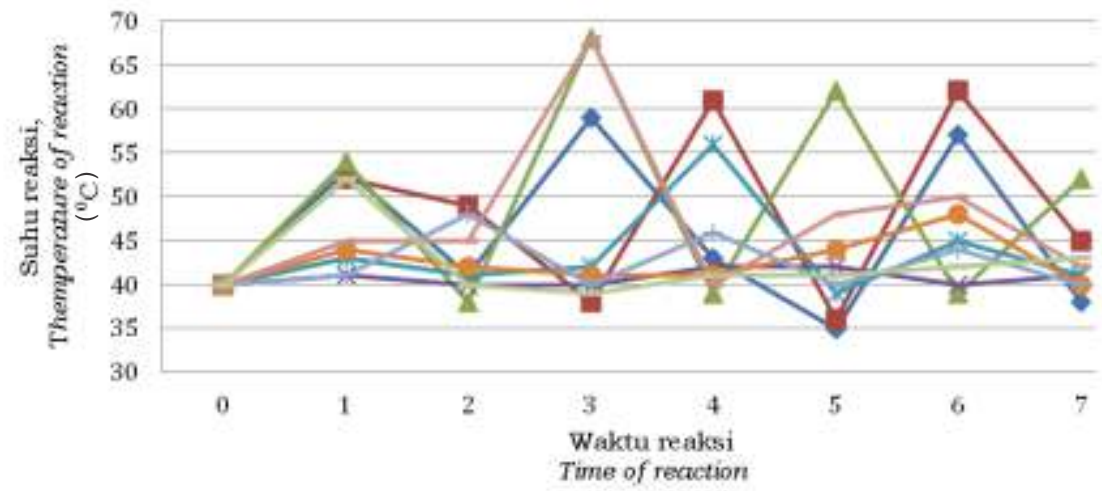

Gambar 3. Perubahan suhu reaksi pada kondisi suhu awal $40^{\circ} \mathrm{C}$

Figure 3. Temperature of reaction changes at initial temperature of $40^{\circ} \mathrm{C}$

Keterangan (remaks) :
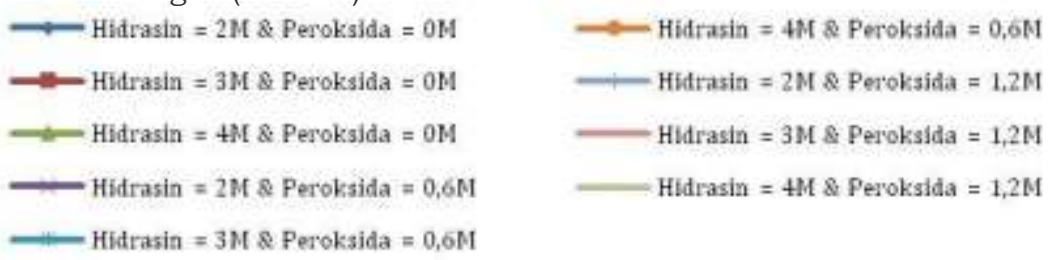

Rendemen yang diperoleh dari reaksi hidrogenasi minyak jarak castor berada pada kisaran 38-68\%. Rendemen terbesar dicapai pada kondisi reaksi pada konsentrasi hidrasin hidrat $55 \%$ sebesar $2 \mathrm{M}$ dan hidrogen peroksida $42 \%$ sebesar $0,6 \mathrm{M}$ pada suhu $40^{\circ} \mathrm{C}$. Besarnya rendemen dipengaruhi oleh kesempurnaan reaksi hidrogenasi. Semakin sempurna reaksi hidrogenasi maka terjadinya reaksi dan produk samping semakin kecil sehingga diperoleh rendemen yang tinggi. Rendemen reaksi juga dipengaruhi oleh keberhasilan pemisahan impurities (air) yang terdispersi dalam minyak terhidrogenasi.

Derajat hidrogenasi menjadi parameter utama dalam penilaian keberhasilan reaksi hidrogenasi. Derajat hidrogenasi merupakan konversi dari reaksi hidrogenasi minyak jarak castor. Pada percobaan ini, nilai derajat hidrogenasi diperhitungkan dari penurunan bilangan iod dan luas serapan 3010 (hasil dari uji spektrofotometri FTIR). Penentuan derajat hidrogenasi berdasarkan penurunan bilangan iod dianggap lebih akurat daripada dengan cara spektrofotometri FTIR. Hal ini disebabkan karena uji bilangan iod minyak dapat menggambarkan secara kuantitatif jumlah ikatan rangkap dalam minyak tersebut. Penurunan bilangan iod digunakan 
Tabel 2. Rendemen dan derajat hidrogenasi minyak jarak castor terhidrogenasi Table 2. Yield and hydrogenation level of hydrogenated castor oil

\begin{tabular}{|c|c|c|c|c|}
\hline \multicolumn{2}{|c|}{$\begin{array}{l}\text { Konsentrasi } \\
\text { Concentration } \\
(\mathrm{M})\end{array}$} & \multirow{2}{*}{$\begin{array}{l}\text { Rendemen } \\
\text { Yield } \\
(\%)\end{array}$} & \multicolumn{2}{|c|}{$\begin{array}{c}\text { Derajat hidrogenasi berdasarkan penurunan } \\
\text { Hydrogenation level based on reduction of } \\
\text { (\%) }\end{array}$} \\
\hline $\mathrm{N}_{2} \mathrm{H}_{4} \cdot \mathrm{H}_{2} \mathrm{O}$ & $\mathrm{H}_{2} \mathrm{O}_{2}$ & & $\begin{array}{l}\text { Bilangan iod } \\
\text { Iod number }\end{array}$ & $\begin{array}{l}\text { Luas serapan } 3010 \\
\text { Area of absorbance } \\
3010\end{array}$ \\
\hline \multicolumn{5}{|c|}{ Suhu reaksi $= \pm 25^{\circ} \mathrm{C}$} \\
\hline \multirow{4}{*}{2} & 0 & 63,32 & 9,05 & 1,05 \\
\hline & 0,6 & 62,06 & 38,12 & 33,86 \\
\hline & 1,2 & 63,26 & 17,61 & 38,32 \\
\hline & 0 & 60,27 & 3,38 & 4,12 \\
\hline \multirow[t]{3}{*}{3} & 0,6 & 51,85 & 2,49 & 26,49 \\
\hline & 1,2 & 53,76 & 22,43 & 26,55 \\
\hline & 0 & 66,33 & 7,48 & 9,51 \\
\hline \multirow[t]{2}{*}{4} & 0,6 & 47,40 & 14,03 & 31,27 \\
\hline & 1,2 & 54,09 & 32,71 & 49,96 \\
\hline \multicolumn{5}{|c|}{ Suhu reaksi $=40^{\circ} \mathrm{C}$} \\
\hline \multirow{4}{*}{2} & 0 & 64,27 & 7,76 & 28,92 \\
\hline & 0,6 & 68,48 & 40,65 & 33,35 \\
\hline & 1,2 & 58,68 & 23,60 & 39,26 \\
\hline & 0 & 55,78 & 5,79 & 40,35 \\
\hline \multirow[t]{3}{*}{3} & 0,6 & 63,23 & 34,72 & 34,32 \\
\hline & 1,2 & 37,56 & 29,93 & 36,17 \\
\hline & 0 & 45,99 & 3,63 & 38,87 \\
\hline \multirow[t]{2}{*}{4} & 0,6 & 56,22 & 15,24 & 33,02 \\
\hline & 1,2 & 51,82 & 28,33 & 50,77 \\
\hline
\end{tabular}

sebagai indikasi terjadinya pemutusan ikatan rangkap dalam molekul trigliserida minyak akibat dari reaksi hidrogenasi. Derajat hidrogenasi berdasarkan perhitungan penurunan bilangan iod tertinggi $(40,65 \%)$ diperoleh pada kondisi reaksi pada konsentrasi hidrasin hidrat $55 \%$ sebesar $2 \mathrm{M}$ dan hidrogen peroksida $42 \%$ sebesar $0,6 \mathrm{M}$ pada suhu $40^{\circ} \mathrm{C}$.

Penggolongan mutu minyak jarak castor terhidrogenasi sebagai bahan pelunak didasarkan pada hasil uji karakterisasinya yang meliputi uji bilangan iod, bilangan asam, berat jenis, kekentalan (viskositas Brookfield), dan FTIR. Hasil karakterisasi minyak jarak castor terhidrogenasi disajikan pada Tabel 3.

Berdasarkan nilai bilangan iod, bahan pelunak karet jenis minyak nabati terhidrogenasi dapat digolongkan menjadi tipe I dengan syarat bilangan iod sebesar 0-5 dan tipe II pada bilangan iod sebesar 55-80 (Ash dan Ash, 2007). Dari Tabel 3 diketahui bahwa minyak jarak castor terhidrogenasi hasil percobaan termasuk Tipe II. Penurunan bilangan iod dari reaksi hidrogenasi dianggap belum signifikan (49-80). Minyak jarak castor yang belum terhidrogenasi memiliki bilangan iod sebesar 83,13. Penurunan bilangan iod yang belum signifikan disebabkan karena konsentrasi hidrasin hidrat dan hidrogen peroksida belum mampu membentuk senyawa diimide dalam jumlah yang cukup untuk mengadisi seluruh ikatan rangkap trigliserida dalam minyak jarak castor. Terjadinya reaksi samping diperkirakan turut mempengaruhi rendahnya penurunan bilangan iod.

Bilangan asam minyak jarak castor terhidrogenasi mengalami peningkatan dari kondisi sebelum reaksi hidrogenasi (bilangan asam minyak jarak castor awal sebesar 1,91). Tingginya bilangan asam minyak jarak castor terhidrogenasi disebabkan oleh bagian trigliserida minyak jarak castor yang tidak terhidrogenasi mengalami reaksi hidrolisis oleh air membentuk asam lemak 
Tabel 3. Karakterisasi minyak jarak castor terhidrogenasi

Table 3. Characterization of hydrogenated castor oil

\begin{tabular}{|c|c|c|c|c|c|c|}
\hline \multicolumn{2}{|c|}{$\begin{array}{l}\text { Konsentrasi } \\
\text { Concentration } \\
\text { (M) }\end{array}$} & \multirow{2}{*}{$\begin{array}{l}\text { Bilangan } \\
\text { iod } \\
\text { Iod number }\end{array}$} & \multirow{2}{*}{$\begin{array}{c}\text { Bilangan } \\
\text { asam } \\
\text { Acid } \\
\text { number }\end{array}$} & \multirow{2}{*}{$\begin{array}{l}\text { Massa jenis } \\
\text { Density } \\
(\mathrm{g} / \mathrm{ml})\end{array}$} & \multirow{2}{*}{$\begin{array}{c}\text { Viskositas } \\
\text { Brookfields } \\
\text { Brookfields } \\
\text { Viscosity } \\
\text { (Cp) }\end{array}$} & \multirow[t]{2}{*}{ FTIR $^{*}$} \\
\hline $\mathrm{N}_{2} \mathrm{H}_{4} \cdot \mathrm{H}_{2} \mathrm{O}$ & $\mathrm{H}_{2} \mathrm{O}_{2}$ & & & & & \\
\hline \multicolumn{7}{|c|}{ Suhu reaksi $= \pm 25^{\circ} \mathrm{C}$} \\
\hline \multirow{4}{*}{2} & 0 & 75,61 & 4,51 & 0,9654 & 495 & + \\
\hline & 0,6 & 51,44 & 3,64 & 0,9603 & 495 & + \\
\hline & 1,2 & 68,49 & 3,75 & 0,9603 & 530 & + \\
\hline & 0 & 80,32 & 4,32 & 0,9601 & 488 & + \\
\hline \multirow[t]{3}{*}{3} & 0,6 & 81,06 & 4,85 & 0.9605 & 535 & + \\
\hline & 1,2 & 64,48 & 4,27 & 0,9605 & 525 & + \\
\hline & 0 & 76,91 & 3,58 & 0,9634 & 440 & + \\
\hline \multirow[t]{2}{*}{4} & 0,6 & 71,47 & 4,55 & 0,9600 & 530 & + \\
\hline & 1,2 & 55,94 & 4,19 & 0,9603 & 515 & + \\
\hline \multicolumn{7}{|c|}{ Suhu reaksi $=40^{\circ} \mathrm{C}$} \\
\hline \multirow{4}{*}{2} & 0 & 76,68 & 2,52 & 0.9624 & 505 & + \\
\hline & 0,6 & 49,34 & 3,82 & 0,9600 & 535 & + \\
\hline & 1,2 & 63,51 & 4,45 & 0,9615 & 510 & + \\
\hline & 0 & 78,32 & 1,91 & 0,9615 & 495 & + \\
\hline \multirow[t]{3}{*}{3} & 0,6 & 54,27 & 4,42 & 0,9617 & 530 & + \\
\hline & 1,2 & 58,26 & 5,07 & 0.9609 & 510 & + \\
\hline & 0 & 80,11 & 1,76 & 0,9619 & 495 & + \\
\hline \multirow[t]{2}{*}{4} & 0,6 & 70,46 & 4,61 & 0,9591 & 530 & + \\
\hline & 1,2 & 59,58 & 5,24 & 0,9612 & 505 & + \\
\hline
\end{tabular}

Keterangan (remaks) :

+ terdapat penurunan luas areal serapan pada daerah 3010

reduction in area of absorbance 3010

bebas. Air terbentuk dari hasil samping reaksi hidrogenasi. Pemisahan air yang tidak sempurna dari minyak jarak castor terhidrogenasi tersebut yang menghidrolisis trigliserida dalam minyak jarak castor terhidrogenasi.

Reaksi hidrogenasi hanya sedikit mengubah massa jenis dan kekentalan minyak jarak castor. Berkurangnya ikatan rangkap dalam susunan molekul trigliserida minyak jarak castor, menyebabkan minyak jarak castor memiliki massa jenis dan kekentalan yang sedikit lebih tinggi. Massa jenis minyak jarak castor awal sebesar $0,9556 \mathrm{~g} / \mathrm{ml}$.

Pada hasil pengujian FTIR, spektrum minyak jarak castor terhidrogenasi tampak terjadi pengurangan luas areal pada puncak serapan gugus $\mathrm{C}=\mathrm{C}$ (Bilangan gelombang $3010 \mathrm{~cm}^{-1}$ ) dan peningkatan pada gugus $\mathrm{CH}$, karena ikatan rangkap $\mathrm{C}=\mathrm{C}$ diadisi oleh $\mathrm{H}$
(Bilangan gelombang 2800-2900 $\mathrm{cm}^{-1}$ ). Hal ini terlihat jelas pada spektrum FTIR reaksi hidrogenasi minyak jarak castor pada kondisi $40^{\circ} \mathrm{C}, 7$ jam dengan penambahan $2 \mathrm{M}$ hidrasin hidrat $55 \%$ dan $0,6 \mathrm{M}$ hidrogen peroksida 42\% (Gambar 4).

Berdasarkan hasil pembuatan dan karakterisasi sifat kimia bahan pelunak alami dari minyak jarak castor melalui reaksi hidrogenasi menggunakan senyawa diimide dapat diketahui bahwa kondisi teroptimal dicapai pada:

Konsentrasi hidrasin hidrat 55\% $=2 \mathrm{M}$

$\square$ Konsentrasi hidrogen peroksida $42 \%$ $=0,6 \mathrm{M}$

$\checkmark$ Suhu reaksi $=40^{\circ} \mathrm{C}$

Waktu reaksi

$=7 \mathrm{jam}$ 


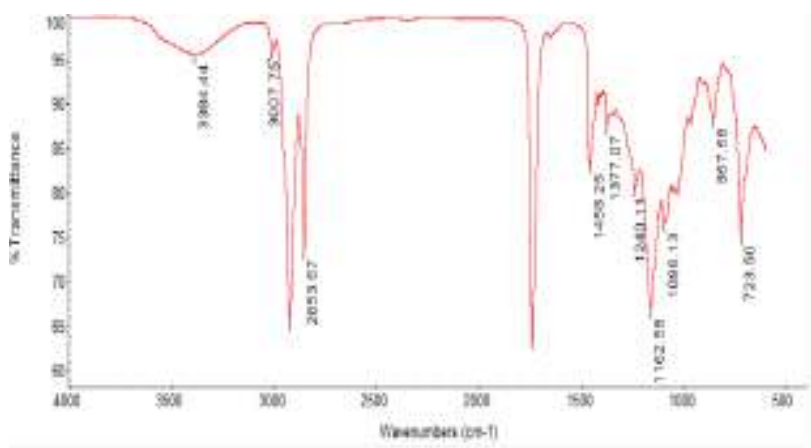

Gambar 4. Spektrum FTIR minyak jarak terhidrogenasi Figure 4. FTIR spectrum of hydrogenated castor oil

Kondisi reaksi hidrogenasi teroptimal tersebut diujicobakan pada pembuatan minyak jarak castor terhidrogenasi berkapasitas $500 \mathrm{ml}$ minyak/batch. Pembuatan minyak jarak castor terhidrogenasi pada skala $500 \mathrm{ml}$ minyak/batch dilakukan sebanyak 2 kali. Hasil percobaan menunjukkan bahwa suhu eksotermis tertinggi mencapai $57-59^{\circ} \mathrm{C}$, saat reaksi timbul banyak buih dan gas, minyak akhir berwarna kuning keruh dan berwujud cairan kental. Rendemen reaksi diketahui sebesar $69,84 \%$ sedangkan derajat hidrogenasi berdasarkan penurunan bilangan iod mencapai 20,51\%. Minyak jarak castor terhidrogenasi yang diperoleh diuji sifat kimia, sifat fisika, serta visualisasi sesuai dengan parameter pada pengujian bahan pelunak karet (Tabel 4). Pengujian sifat kimia meliputi bilangan iod dan bilangan asam. Bilangan iod minyak jarak castor terhidrogenasi sebesar 66,08 dan bilangan asam sebesar 3,69.

Derajat hidorgenasi berdasarkan penurunan bilangan iod minyak jarak castor terhidrogenasi yang disintesis pada skala $500 \mathrm{ml}$ minyak/ batch lebih rendah daripada minyak jarak castor yang dihidrogenasi pada skala $300 \mathrm{ml}$ minyak/batch. Hal ini dipengaruhi oleh kecepatan pengadukan saat reaksi. Kecepatan pengadukan berperan dalam kinetika reaksi terutama pada penentuan laju reaksi. Pada percobaan baik untuk skala $300 \mathrm{ml}$ minyak/batch maupun $500 \mathrm{ml}$ minyak/batch ditetapkan kecepatan pengadukan dan waktu yang sama. Akibatnya tumbukan antar partikel pereaksi pada skala $500 \mathrm{ml}$ minyak/batch menjadi lebih sedikit.

Hasil pengujian sifat fisika minyak jarak castor terhidrogenasi (HCO) sebagai bahan pelunak karet alami dituangkan dalam Tabel 4. Minyak jarak castor terhidrogenasi memiliki struktur molekul

Tabel 4. Sifat bahan pelunak golongan minyak parafinik Table 4. Properties of paraffinic plasticizer

\begin{tabular}{|c|c|c|c|c|c|}
\hline \multirow[t]{2}{*}{ No } & \multirow{2}{*}{$\begin{array}{c}\text { Sifat } \\
\text { Properties }\end{array}$} & \multirow{2}{*}{$\begin{array}{l}\text { Metode } \\
\text { Method }\end{array}$} & \multicolumn{3}{|c|}{$\begin{array}{c}\text { Bahan pelunak parafinik } \\
\text { Paraffinic plasticizer }\end{array}$} \\
\hline & & & HVI 60* & HVI $650^{*}$ & $\mathrm{HCO}$ \\
\hline 1 & $\begin{array}{l}\text { Kekentalan } \\
\text { Viscosity at } 100{ }^{\circ} \mathrm{C}, \mathrm{cSt}\end{array}$ & ASTM 0-445 & $4,4-4,9$ & $30,5-33,5$ & 21,70 \\
\hline 2 & $\begin{array}{l}\text { Titik nyala } \\
\text { Flash point } \mathrm{PMCC} .{ }^{\circ} \mathrm{C}(\mathrm{min})\end{array}$ & ASTM D-93 & 204 & 267 & 108,5 \\
\hline 3 & $\begin{array}{l}\text { Titik tuang } \\
\text { Pour point, }{ }^{\circ} \mathrm{C}(\max )\end{array}$ & ASTM D-97 & -15 & - & $<-36$ \\
\hline 4 & $\begin{array}{l}\text { Kadar abu } \\
\text { Ash content, \% wt (max) }\end{array}$ & ASTM 0-482 & 0,01 & 0,01 & 0,03 \\
\hline 5 & $\begin{array}{l}\text { Warna } \\
\text { Color ASTM (max) }\end{array}$ & ASTM 0-1500 & 1,5 & 4,0 & 1,5 \\
\hline 6 & $\begin{array}{l}\text { Visualisasi } \\
\text { Appearance }\end{array}$ & Visual & $\begin{array}{l}\text { Terang } \\
\text { Clear }\end{array}$ & $\begin{array}{l}\text { Terang } \\
\text { Clear }\end{array}$ & $\begin{array}{l}\text { Terang } \\
\text { Clear }\end{array}$ \\
\hline
\end{tabular}


rantai lurus yang menyerupai minyak parafinik komersial (HVI 60 dan HVI 650). Berdasarkan Tabel 4 diketahui bahwa minyak jarak castor terhidrogenasi (HCO) memiliki sifat yang belum menyerupai minyak parafinik komersial HVI 60 dan 650 terutama dalam hal kekentalan, titik nyala, dan titik tuang.

\section{KESIMPULAN DAN SARAN}

Kondisi optimal dalam sintesis bahan pelunak karet alami dari minyak jarak castor melalui reaksi hidrogenasi oleh senyawa diimide pada kapasitas $300 \mathrm{ml}$ minyak/batch diperoleh pada penambahan hidrasin hidrat $55 \%$ sebesar $2 \mathrm{M}$ dan hidrogen peroksida sebesar $0,6 \mathrm{M}$ pada suhu reaksi $40^{\circ} \mathrm{C}$ selama 7 jam. Reaksi ini menghasilkan minyak jarak terhidrogenasi yang dapat digolongkan dalam bahan pelunak Tipe II karena memiliki bilangan iod sebesar 49,34. Pada penelitian selanjutnya, uji coba minyak jarak castor terhidrogenasi sebagai bahan pelunak dalam pembuatan kompon karet perlu dilakukan guna mengetahui kelayakan kinerja minyak jarak castor sebagai bahan pelunak kompon karet.

\section{DAFTAR PUSTAKA}

Arizal, Ridha. 1990. Pengaruh Hasil Analisa Kimia Bahan Pelunak-Minyak Terhadap Kompon dan Vulkanisat Karet. Prosiding Lokakarya Processing Oil'90. Jakarta, 27-28 Februari. Pusat Pengendalian Mutu Petrokimia.: 1-9

Ash, M. and I. Ash. 2007. Handbook of Fillers, Extender, and Diluents, $2^{\text {nd }}$ Edition. Synapse Information Resources Inc, New York.

Badan Pusat Statistik. 2010. Ekspor Impor Tahun 2010. Badan Pusat Statistik, Jakarta.
Kraft, V., G. Kretzschmar, and K. Rossen. 2011. Process for the Production of Atermisinin Intermediate. US Patent 0230669 A 1.

Lin, Xingwang, Q. Pan, and G.L. Rempel. 2003. Cupric Ion Catalyzed Diimide Production From The Reaction Between Hydrazine And Hidrogen Peroxide, J.Applied.Catalysis A: General 263: 27-32,DOI : 10.1016/j.apcata.2003.11.035

McMillan, F.M. 1959 Rubber, Softener, and Extenders. In Morton, M. 1959 Introduction to Rubber Technology. Reinhold Publishing Co, New York

Naglic, M., A. Smidounik, and T. Kolini. 1998. Kinetic of Catalytic Transfer Hydrogenation of Some Vegetable oils JAOCS 75: 629-633

Parker, D.K, and D.M. Rithenburg. 1995. The Goodyear Tire \& Rubber Company. US Patent 5424356

Pertamina.2013. Lube Base Oil. Pertamina, Jakarta. www.pertamina.com di akses tanggal 2 Januari 2013

Smit, C., M.W. Fraaije., and A.J. Minnaard. 2008. Reduction of Carbon-Carbon D o u ble B o n d s U s i n g Organocatalytically Generated Diimide, J.Org.Chem 73(23): 9482-9485

Suseno, Rs Suwarti. 1990. Memanfaatkan Bahan Pembantu Produk Dalam Negeri Untuk Industri Karet. Prosiding Lokakarya Processing Oil'90. Jakarta, 27-28 Februari. Pusat Pengendalian Mutu Petrokimia.: 1-15 